\title{
Land use change in highland area and its impact on river water quality: a review of case studies in Malaysia
}

\author{
Azlini Razali ${ }^{1}$, Sharifah Norkhadijah Syed Ismail ${ }^{1 *}$, Suriyani Awang², Sarva Mangala Praveena ${ }^{1}$ \\ and Emilia Zainal Abidin ${ }^{1}$
}

\begin{abstract}
The policy of encouraging agriculture and development for mass tourism has led to environmental problems in Cameron Highlands, Malaysia. Rampant development and land clearing have significantly altered the land cover of Cameron Highlands for the past 30 years. Sensitive highlands areas are prone to landslides and soil erosion which then contributed to the main water pollution issues in the network of river system, sedimentation and siltation. The continuous trend of river water quality deterioration in Cameron Highlands has raised the issues for discussion in this review article. The purpose of this review is to briefly summarize the land use change, agriculture practices, agro-tourism, and agriculture policy and management toward water quality of the river system network in Cameron Highlands specifically in the downtown where most of the development and agriculture activities are concentrated. A rigorous review has been done on the existing literature to determine the relationship between land use change and agriculture practices toward river water quality in Cameron Highlands from 2001 to 2017. The total number of reviewed papers was 68 . The outcomes established from previous researchers have highlighted factors such as soil erosion, landslides, agriculture activities, urbanization, and unplanned development associated with land use change have significantly influenced the river water quality in the highland areas. Continuous land use changes without proper development plan and law enforcement may critically threaten the sustainability of river network in the highlands area.
\end{abstract}

Keywords: Agriculture, River water quality, Highlands, Land use, Soil erosion, Cameron Highlands

\section{Introduction}

Land use is the utilization of land resources by humans for various land activities and purposes such as for recreational (park), transport (road and railway), agriculture (farm), residential (housing and settlements), and commercial (business and factories) (Rendana et al. 2015). Land use/land change (LULC) alter the natural ecosystem services via (1) modifying the ecological structure and functions, (2) influencing human demand for ecosystem services, (3) affecting the non-natural capital (e.g., infrastructure) providing human access to ecosystem services (Sonter et al. 2017).

Highland regions act as water catchment and serve as the main hydropower generation sources for lowland. It also

\footnotetext{
* Correspondence: norkhadijah@upm.edu.my

${ }^{1}$ Department of Environmental and Occupational Health, Faculty of Medicine and Health Sciences, Universiti Putra Malaysia, 43400 Serdang, Selangor, Malaysia

Full list of author information is available at the end of the article
}

provides water resources for agricultural, industrial, and domestic use downstream (Roozitalab et al. 2013). The areas that have elevation more than $1000 \mathrm{~m}$ are categorized as mountains, 100 to $1000 \mathrm{~m}$ as hills, and 30 to $100 \mathrm{~m}$ as developable land (Gasim et al. 2009). According to Malaysia Islands and Highlands Development Guideline, any forest lands situated $1000 \mathrm{~m}$ above the sea level are classified as reserved forest or catchment forest land. Thus, any land clearing is prohibited in this area as it is an environmentally sensitive area (Tan and Mokhtar 2011). Moreover, high altitude results in higher rate of chemical loss from soil erosion into the river (Saadati et al. 2012) and cultivation on steep slopes areas triggered soil erosion (Lantican et al. 2003). Common steps in opening new land for agriculture are land clearing, burning, land leveling, terracing, bed preparation, and planting (Aminuddin et al. 2001). Agriculture practices done in fragile highlands area especially in steep slopes tend 
to cause an on and off farms pollution toward the environment (Barrow et al. 2009).

In Peninsular Malaysia, the main highlands regions including Upper Perak-Galas, Upper Pergau, Upper KintaJelai, Upper Jelai-Tahan, Upper Selangor-Semantan, and Upper Endau-Rompin (Rozimah and Khairulmaini 2016). Cameron Highlands is the smallest district of Pahang bordering Kelantan on the north, Perak on the west, and Lipis district on the south-east (Fig. 1). The total area of Cameron Highlands is 71, 225 ha comprising of three main subdistricts (mukim) which are Hulu Telom (63, 990 ha), Ringlet (5, 165 ha), and Tanah Rata (2070 ha). Cameron Highlands is one of the most famous retreat locations in Malaysia located in the high-elevation central of Titiwangsa Range, where the highest peak is Gunung Irau (2110 m). Approximately, more than $74 \%$ of the total area has an elevation of more than $1000 \mathrm{~m}$ with a cold climate and scenic landscape. According to Cameron Highlands Local Development Plan (RTD 2018a), almost 29\% of the land in Cameron Highland are having steep slopes with a gradient greater than $25^{\circ}(18,226 \mathrm{ha}, 26 \%)$ to $35^{\circ}$ (2039 ha, 3\%). Areas with steep slopes exceeding $25^{\circ}$ have a high risk of soil erosion and are not suitable for development (Aminuddin et al. 2001; RTD 2018a). Located in a highland elevation, the average temperature of Cameron Highlands is between $17^{\circ}$ $\mathrm{C}$ and $20^{\circ} \mathrm{C}$ all year round. However, the local temperature has risen up to $5{ }^{\circ} \mathrm{C}$ in 2014 compared to the past 15 years (RTD 2003). Maximum rainfall (wet season) is during October to November and April to May while minimum rainfall (dry season) is during January to March and June to August. There are three main rivers that flow across Cameron Highlands which are the Telom River $(37 \mathrm{~km})$ at the north, Bertam River $(20 \mathrm{~km})$ at the middle, and Lemoi River $(16 \mathrm{~km})$ (Fig. 2). All these rivers flow eastward to form the Jelai River which then fused with Tembeling River and form Pahang River (459 km), the longest river on Peninsular Malaysia and drains into the South China Sea (Khalik et al. 2013a; RTD 2018a). On the westward, the rivers are being drained into the Perak River into the Straits of Melaka. This complex river system consists of 123 tributaries particularly located within the Telom River and Bertam River. These rivers serve as freshwater sources, hydroelectricity generation, and irrigation for agriculture purposes and are for recreational activities (Gasim et al. 2009). Tourism and highland agriculture are the main economies driven in Cameron Highlands.

In 2015, there was an almost 3\% reduction on forest coverage in Cameron Highlands, and the land use for agriculture activities has increased. Inefficient law enforcement have cause many illegal land clearings, which trespass the forest reserve and riverbank areas, and unsustainable developing methods (e.g., farming on steep slopes, rain shelter, installation of irrigation pipes on the road sideways and in the slope, excessive usage of pesticides and fertilizers, soil erosion and high sedimentation rate in riverbed) have create major ecological disturbances in Cameron Highlands (Raj 2002; Aminuddin et al. 2005; Barrow et al. 2009; Khairulmaini and Fauza 2010; Mohd Ariffin et al. 2014; Weebers and Idris 2016).

National Audit Report 2012 in RTD 2030 has highlighted several issues of agriculture development of Cameron Highlands (RTD 2018b). Intensive land clearing and deforestation for agricultural activities were reported in this area where most of the agricultural activities were operated illegally without the permission of the authority. There also issues of poor collaboration and coordination between authorized stakeholders (i.e., land and mines office) on the granting of permits and approvals for land use even in the sensitive and high-risk areas, although the action does not comply with

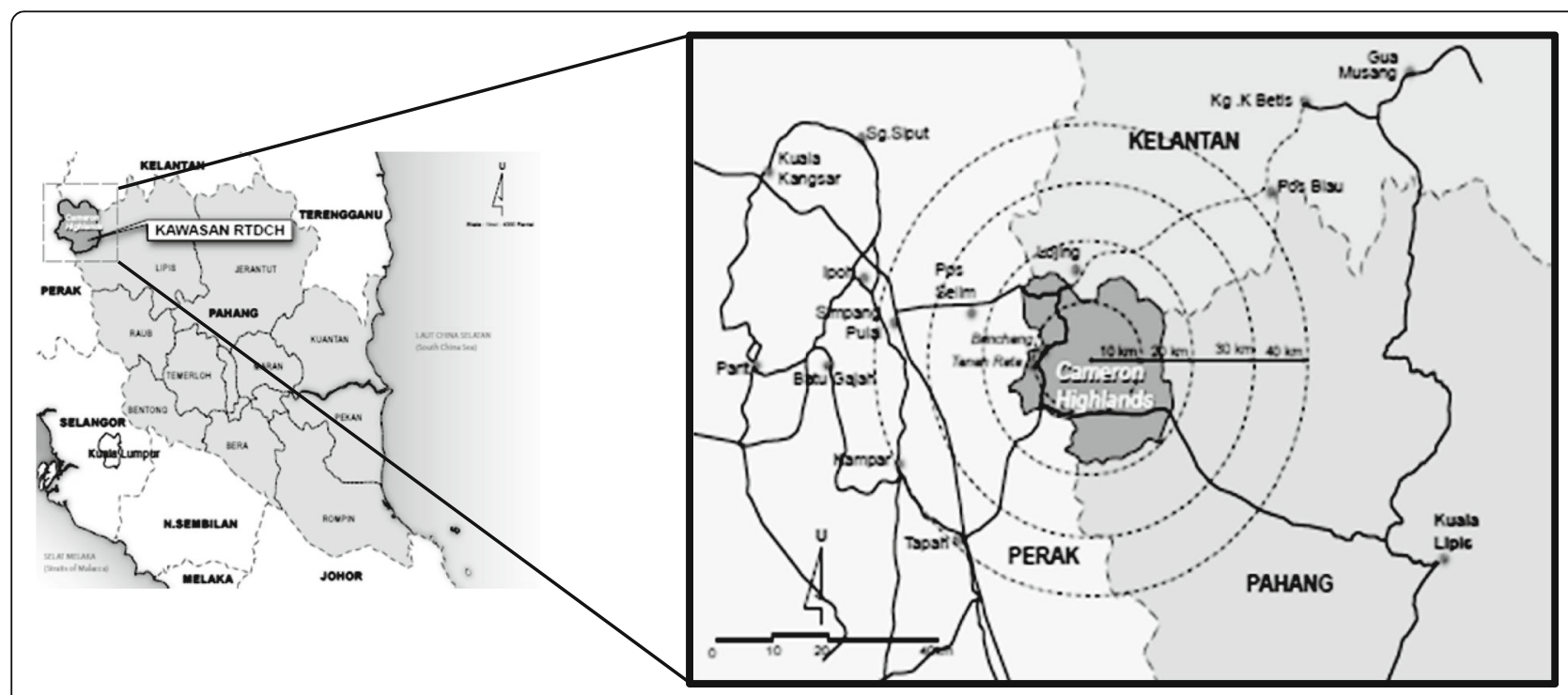

Fig. 1 Case study location located in Cameron Highlands, the smallest district in Pahang, Peninsular Malaysia (RTD 2018a) 


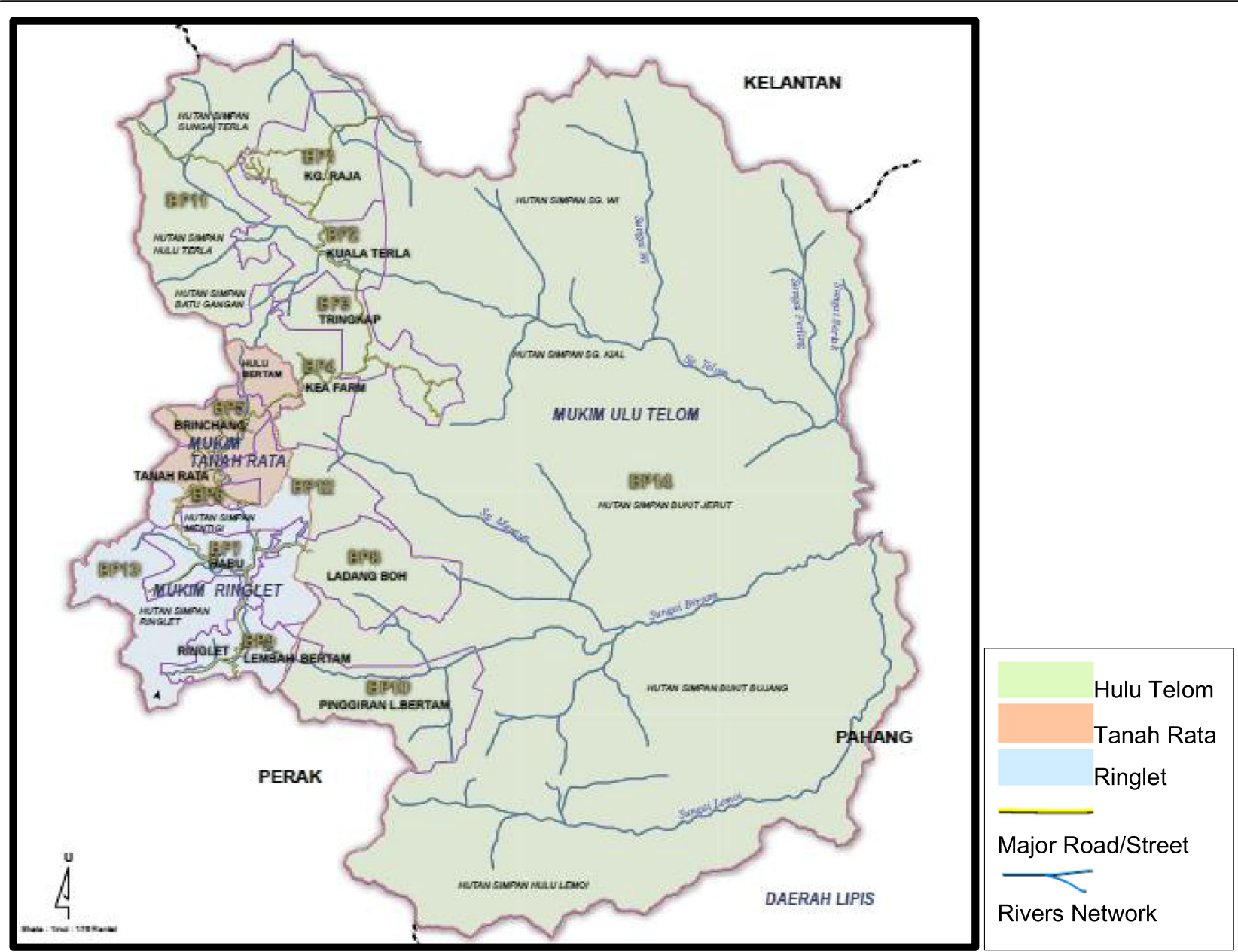

Fig. 2 Map of Cameron Highlands with three major sub-districts: Hulu Telom, Tanah Rata and Ringlet. The map also visualizes the rivers channel networks within the highlands area (RTD 2018a)

the conditions according to the environmental department and the department of water and drainage. Furthermore, inadequate law enforcement action on trespassing and illegal activities in this area had caused the agricultural activities to continue breaking the laws. This has been proven by satellite images, where the land clearing for a new development of the agricultural area has exceeded the permitted area by the authority.

The objectives of this review were to explore the connections between the land use activity, agriculture practices, agro-tourism, and agriculture policy and management with the water quality effects in the river network of Cameron Highlands. The continuous deterioration of the river water quality in this area has become the major concern especially when it can affect human health as well as the environment.

\section{Methodology}

A rigorous review has been done in the existing literature. This article explores the impact of land use changes, agriculture practices, agro-tourism, and agriculture policy and management toward the river system in highlands area, Malaysia. The total numbers of paper reviewed were 68. The literature search was performed through major scientific literature databases including Scopus, Science Direct, Springer, Google Scholar, and EZproxy UPM library search engines with the following keywords: Cameron Highlands, Bertam catchment, water quality, water quality index (WQI), physicochemical, agriculture, and land use. From this search, we focused on the papers which are directly empirical and related with the keywords via detailed screening. There are no field data collections or laboratory water quality analysis involve in this study.

\section{Result and discussion}

Land use change for the past $\mathbf{5 0}$ years in Cameron Highlands

The forest and natural areas in Cameron Highlands were reported to have been decreased from 67,381 ha in 1966 to 58,855 ha in 2010. Pearson Correlation Coefficient has 
found a correlation between forest degradation and the developed land use in Cameron Highlands Land Use Map (1966-2010) (Rozimah and Khairulmaini 2016). The coefficient value showed a significant association between the increase of development land use and the decrease of natural and forest areas. The land use for vegetable farming showed the highest trend with a sharp increase of $672 \%$ from 1966 to 2010 especially in the areas nearby Bertam and Telom catchment areas, followed by other land uses (shrub, grass and orchard) (576\%) and urban development (100\%) (substantially at Tanah Rata and Brinchang). Most of the development concentrated in the west part of Cameron Highlands and nearby the river bank (Rozimah and Khairulmaini 2016). The encroachment of river reserve areas for agriculture can be proved by the decrease of the water bodies from 237 ha in 1984 to 177 ha in 2002 (Gasim et al. 2009).

In another study by Gasim et al. (2010), a significant change in the land use pattern from 1984 to 2002 have been reported. The urbanization area has increased from 181 ha in 1984 to 306 ha in 2002 while the agriculture land use has increased from 438 ha in 1984 to 2926 ha in 2002. On the other hand, the forest area has been significantly reduced from 30,989 ha in 1984 to 23,374 ha in 2002.

Rendana et al. (2015) have reported the land use change in the past, present, and future in the catchment area of Cameron Highlands through Cellular AutomataMarkov chain. They have reported that the forest and wetland area have decreased from 58,689 ha in 1997 to 54,264 ha in 2014. The agricultural area has increased from 6710 ha in 1997 to 7527 ha in 2014. The Cellular Automata-Markov chain also has predicted the future land use change in this area where forest area is expected to decrease by 1202 ha, while mixed agricultural area is expected to increase by 501 ha in 2020 .

According to the Malaysian Federal Law under National Forestry Act 1984 (Peninsular Malaysia), development on forest within the private lot is legal while development on reserve lot such as reserve forest that belongs to the government property is illegal and is considered as land encroachment. Zin and Ahmad (2014) have successfully identified the area of land encroachment on the government land, mostly forest area by utilizing the optical images from IKONOS and SPOT 2001-2010 particularly at the area in Brichang and Habu. These areas have been reported to experience illegal invasion for land clearing by the local newspaper. The encroachment area was identified 297 ha in 2001 and it has increased by 32\% in 2010 to 390.41 ha particularly for agriculture.

However, another study has reported an improved succession of the secondary forest in an abandoned mixed agricultural area which have increased by $2 \%$ from 2000 to 2010 (Ismail et al. 2012).
Rozimah and Khairulmaini (2016) have reported four main environmental issues in Cameron Highlands, namely as river pollution (98 cases), slope failure (69 cases), temperature rising (35 cases), and flood (7 cases).

The effect of deforestation and land clearing can be measured by the temperature changes. A slight elevation of average temperature from 2.0 to $2.2{ }^{\circ} \mathrm{C}$ in Cameron Highlands has been determined for the past 33 years to be associated with deforestation and land clearing (Barrow et al. 2009; Gasim et al. 2010). The accumulation of carbon dioxide and carbon monoxide associated with the high use of motor vehicles also had caused the local temperature increment (Rozimah and Khairulmaini 2016). Apart from deforestation, the construction of hydroelectric dam in Cameron Highlands has diverged and manipulated the natural river flows which consequently have changed the energy flow and matter in rivers. However, the hydroelectric power system only causes nominal change compared to large-scale land clearing, agriculture and development (Khairulmaini and Fauza 2010).

Land use changes greatly influence the surface runoff into water bodies. Agriculture activity contributes the highest total nitrogen and total phosphorus runoff as compared to the residential areas, urban areas, and vacant areas (Eisakhani et al. 2009). The increasing trend of conversion of land use into agriculture areas significantly increases the introduction of eroded soil into water bodies (Haron et al. 2014).

Table 1 summarized the land use change in Cameron Highlands from the existing literature. Overall, it can be concluded, as the land use for agriculture keeps increasing and expanding, the land use for forest will continue to shrink and decrease and significantly contribute to environmental changes such as the local temperature, surface runoff, and other pollution. Owing to this fact, appropriate land use planning is very crucial especially in steep and highland areas to control the effects.

\section{Agriculture practices and agro-tourism in Cameron Highlands}

Terracing and leveling for plantation on steep slopes in Cameron Highlands displaced all the naturally present nutrients on the habitat topsoil. Thus, farmers usually will use the untreated organic fertilizers such as chicken manure to the newly open land. Barrow et al. (2009) have reported that farmers favor the untreated chicken manure as fertilizers because of the richness in the nitrogen (NPK) content that helps to speed up and elevate the growth of their crops. Almost $84 \%$ of 152 interviewed farmers used uncomposted and untreated chicken manure, and the application rate was between 10 and $75 \mathrm{t}$ ha/year.

Chemical pesticides such as indoxacarb, fipronil, chlorpyrifos combined with cypermethrin, lambda-cyhalothrin, and abamectin have been preferably used by more than 
Table 1 Percentage of land use/land change (LULC) from previous studies

\begin{tabular}{|c|c|c|c|c|c|c|c|c|c|c|c|c|c|}
\hline No. & References & $\begin{array}{l}\text { Land use/years } \\
\text { (ha) }\end{array}$ & 1947 & 1966 & $\begin{array}{l}1982- \\
1984\end{array}$ & 1990 & 1995 & 1997 & $\begin{array}{l}2000- \\
2003\end{array}$ & 2005 & 2010 & $\begin{array}{l}2014- \\
2016\end{array}$ & $\begin{array}{l}\text { Changes } \\
(\%)\end{array}$ \\
\hline \multirow[t]{3}{*}{1} & \multirow[t]{3}{*}{ Gasim et al. 2009} & Urbanization & - & - & 181 & - & 264 & - & 306 & - & - & - & $+69 \%$ \\
\hline & & Agriculture & - & - & 438 & - & 1402 & - & 2926 & - & - & - & $+568 \%$ \\
\hline & & Forest & - & - & 30,989 & - & 27,766 & - & 23,374 & - & - & - & $-25 \%$ \\
\hline \multirow[t]{2}{*}{2} & \multirow[t]{2}{*}{ Ismail et al. 2012} & Developed $^{\mathrm{a}}$ & - & - & - & - & - & - & 9408 & 8707 & 8668 & - & $-8 \%$ \\
\hline & & Natural areas ${ }^{b}$ & - & - & - & - & - & - & 17,570 & 18,262 & 18,245 & - & $+4 \%$ \\
\hline \multirow[t]{12}{*}{3} & \multirow{12}{*}{$\begin{array}{l}\text { Khairulmaini and } \\
\text { Fauza } 2010\end{array}$} & \multicolumn{12}{|l|}{ Telom catchment } \\
\hline & & Forest & 10,380 & - & 9040 & 9030 & - & 7410 & - & - & - & - & $-29 \%$ \\
\hline & & Agriculture & 550 & - & 1320 & 1340 & - & 2890 & - & - & - & - & $+81 \%$ \\
\hline & & Urbanization & 0 & - & 50 & 50 & - & 110 & - & - & - & - & $+110 \%$ \\
\hline & & \multicolumn{12}{|l|}{ Upper Bertam } \\
\hline & & Forest & 1950 & - & 1620 & 1590.00 & - & 1540 & - & - & - & - & $-21 \%$ \\
\hline & & Agriculture & 190 & - & 220 & 240.00 & - & 290 & - & - & - & - & $+35 \%$ \\
\hline & & Urbanization & 0 & - & 290 & 300.00 & - & 300 & - & - & - & - & $+300 \%$ \\
\hline & & \multicolumn{12}{|l|}{ Lower Bertam } \\
\hline & & Forest & 4380 & - & 2920 & 2910.00 & - & 2810 & - & - & - & - & $-36 \%$ \\
\hline & & Agriculture & 260 & - & 970 & 1020.00 & - & 1470 & - & - & - & - & $+82 \%$ \\
\hline & & Urbanization & 0 & - & 100 & 110.00 & - & 120 & - & - & - & - & $+120 \%$ \\
\hline \multirow[t]{3}{*}{4} & \multirow[t]{3}{*}{ Haron et al. 2014} & Urbanization & - & - & - & - & - & - & - & - & - & 971 & $2 \%$ \\
\hline & & Agriculture & - & - & - & - & - & - & - & - & - & 9782 & $14 \%$ \\
\hline & & Forest & - & - & - & - & - & - & - & - & - & 57,354 & $84 \%$ \\
\hline 5 & Zin and Ahmad 2014 & Forest reserve & - & - & - & - & - & - & 3533 & - & 3141 & - & $-11 \%$ \\
\hline \multirow[t]{3}{*}{6} & \multirow[t]{3}{*}{ Rendana et al. 2015} & Urbanization & - & - & - & - & - & 126 & - & - & - & 439 & $+249 \%$ \\
\hline & & Agriculture & - & - & - & - & - & 6710 & - & - & - & 7527 & $+12 \%$ \\
\hline & & Forest & - & - & - & - & - & 58,689 & - & - & - & 54,264 & $-8 \%$ \\
\hline \multirow[t]{2}{*}{7} & \multirow{2}{*}{$\begin{array}{l}\text { Rozimah and } \\
\text { Khairulmaini } 2016\end{array}$} & Developed & - & \pm 4000 & - & - & - & - & - & - & $\pm 12,000$ & - & $+200 \%$ \\
\hline & & Natural areas & - & 67,381 & - & - & - & - & - & - & 58,855 & - & $-13 \%$ \\
\hline \multirow[t]{2}{*}{8} & \multirow[t]{2}{*}{ Sholagberu et al. 2016} & Urbanization & - & - & - & - & 593 & - & 830 & - & - & - & $+40 \%$ \\
\hline & & Agriculture & - & - & - & - & 5125 & - & 5671 & - & - & - & $+11 \%$ \\
\hline \multirow[t]{2}{*}{9} & \multirow{2}{*}{$\begin{array}{l}\text { RTD 2003-2015 (RTD 2018a) } \\
\text { and RTD } 2030 \text { (RTD 2018b) }\end{array}$} & Agriculture & - & - & - & - & - & - & 5683 & - & - & 7508 & $+32 \%$ \\
\hline & & Forest & - & - & - & - & - & - & 64,467 & - & - & 62,504 & $-3 \%$ \\
\hline
\end{tabular}

All the total areas presented may not having the same values as the area cover for each study may be different

RTD Rancangan Tempatan Daerah Cameron Highlands/Local District Planning

${ }^{a}$ Land use (mixed agriculture/residential/road + tea plantation)

${ }^{\mathrm{b}}$ Land use (primary forest + secondary forest/shrub

90\% of the farmers to cater with pest and disease control (Mazlan and Mumford 2005). These chemicals were classified ranged from medium to high environmental impact quotient (EIQ) unit that demonstrates the toxicity of the pesticide to human and environment. In general, $3-4$ types of pesticides were used during the crop season and more pesticides were applied during the rainy season to compensate the washed off process during rains (Mazlan and Mumford 2005).

Three main categories of pesticides are used including fungicides, insecticides, and herbicides. Fungicides are the most abundant type of pesticides used which comprised of
$53 \%$, followed by insecticides $44 \%$ and herbicides $3 \%$. Apart from functioning in pest and disease control, a fungicide such as mancozeb also serves to accelerate the vegetative growth and increase the vegetable production. Fungicides such as hexaconazole and tribasic copper sulfate while insecticides such as diafenthiuron, acetamiprid, and cyromyzine fall under class III of the Chemical Hazard Category by World Health Organization (WHO). Class IV insecticides, abamectin also found to be used by the interviewed farmers (Mispan et al. 2015).

Only 16\% of the 99 farmers in Cameron Highlands applied Integrated Pest Management (IPM) such as sticky 
traps, pheromones traps, parasitoids, and crop rotation while others used chemical pest control (Mazlan and Mumford 2005; Aminuddin et al. 2001). The application of fertilizer and pesticides can cause repeated runoff and erosion into the water bodies, particularly during rainfall. Farina et al. (2016) have detected Organochlorine pesticides (OCPs) residues; a chemical pesticide in the agricultural soils. These type of pesticides have high persistence (more than 10 years) and also have a tendency to bio-accumulate in the soil and contaminated the vegetables. Occupational exposure and direct consumption of these vegetables may cause pesticide poisoning (Farina et al. 2016). Heavy metals residual from chemical pesticides and fertilizer such as manganese $(\mathrm{Mn})$, copper $(\mathrm{Cu})$ and zinc $(\mathrm{Zn})$ also among the elements found in the soil from farms in Ringlet and Tanah Rata. Vegetables grown in the contaminated soils have a tendency to accumulate the metals in their tissues, thus pose a health risk to human though consumption (Khairiah et al. 2006). Copper may persist in some organs such as the brain, heart, liver, lungs, and kidneys and disrupt their normal functions. Despite its low toxicity in human, however, Zn might cause nausea, vomiting, accumulation in kidney and stomach (Singh et al. 2011).

The farmers also come out with some innovation to cater with intensive agriculture practices such as plastic rain shelters, shift from vegetable to flower growing, improved seeds, installation of catch drains and sumps, hydroponics, and drip irrigation (Barrow et al. 2009). Cultivation under rain shelter has been practised widely in Cameron Highlands especially for flowers and vegetable farming (e.g., tomato, cucumber and brinjal). This practice provides a protection to that plantation against a direct hit from rain and strong winds. Cultivation under rain shelter also may minimize the soil erosion but the interception of the rainfall due to rain shelter create the bigger amount of runoff and also increase soil salinity (Aminuddin et al. 2001). Moreover, the rain shelter trapped the heat from the sun and projected higher greenhouse gaseous emission which in turn increase the surrounding temperature (Hamdan et al. 2014).

Soil erosion introduced the agriculture soil bounded with pesticides and heavy metal elements into water bodies. Open vegetable farming has the highest erosion rate estimated at $82 \mathrm{t} / \mathrm{ha} /$ year and more than $69 \%$ of the rainfall become runoff that flows into the water bodies carried together with the eroded soil a significant amount of nutrient and heavy metals. In contrast, rain shelter cultivation having less erosion rate estimation as only $1 \mathrm{t} / \mathrm{ha}$ /year and the runoff is about $15 \%$. Tea plantation has minimal soil erosion as it required the least earthwork for cultivation and the dense ground cover that capable to absorb the raindrop impact which proposes as the most sustainable form of farming compared to open vegetable farm (Aminuddin et al. 2001; Barrow et al. 2009).

Apart from soil erosion problem, the water bodies also threatened with agricultural waste runoff and nutrient loss from the expose agriculture soil (Tan and Mokhtar 2011). Good cropping practices such as conservation tillage can minimize the soil erosion and runoff by leaving the residue of the previous crop on the agriculture field after harvesting before and after planting the new crop cycle (Eisakhani et al. 2011).

Cameron Highlands Tourist Association was established in 1960 to develop an agro-tourism activity for this area (Weebers and Idris 2016). Agro-tourism is an agriculturebased operation such as scenic scenery in a tea plantation, strawberry and flowers farms comprehended with education, entertainment and production operation which attract visitors to farms and experiences in the natural agrobased setting (Oliver et al. 2017). The policy of encouraging agriculture and development for mass tourism has led to environmental problems in Cameron Highlands. New highways constructed in 2003, provide a better land access for agriculture products transportation and reduce the cost and time to deliver the goods (Barrow et al. 2009). The 7th Malaysia Plan (1996-2000) has encouraged the participation from local communities to ensure the success of agro-tourism (Mohd Ariffin et al. 2014; Mansor et al. 2015) and strategies have been created to expand the agriculture potential and other relatable sectors specifically agro-tourism in the 8th and 9th Malaysia Plan (20062010). According to RTD 2018a, the tourism focused on agro-tourism, eco-tourism, cultural and heritage tourism. Tourism has led to the economic enhancer in Cameron Highlands (Mohd Ariffin et al. 2014). However, lack attention has been given toward the impact of the activities on triggering the environmental problems (Mansor et al. 2015). Oliver et al. (2017) have reported, $80 \%$ of 100 respondents strongly agreed that agro-tourism in Cameron Highlands threaten the environment as evidently shown by disasters such as landslides, flash floods and mud floods that occur frequently especially after heavy rain pouring. Sustainable tourism will ensure the balance benefit between human and environmental resources and to avoid the human-environment conflict. A sustainable tourism map for Cameron Highlands has been identified by Aminu et al. (2014) and areas that sensitive to human disturbances such as water bodies have been identified as not suitable for agro-tourism activities.

Agriculture policy and management in Cameron Highlands Agriculture activities began to flourish in Cameron Highlands since the 1970s and practice a static shifting cultivation. In the 1990s, Temporary Occupation Licenses (TOLs) under leasing arrangements for 40 years was introduced by the local government to tackle the illegal 
land clearing. TOLs was issued by Cameron Highlands District and Land Office are for temporary use only such as cultivation of non-permanent and seasonal crops; establish a temporary home or construction that can be transferred; public performances such as circus, exhibitions, and others. Some of rules and conditions regarding TOLs are, it cannot be transferred or taken over, terminate when its holders die, can be canceled at any time without any compensation when a breach of the provision is made, and it cannot be used for other purposes apart from what has been stated in the agreement. In accordance with Pahang State Land Administration Directive (Arahan Pentadbiran Tanah Negeri) No. 5/1998, approval for new applications, renewal and re-application of TOLs in Cameron Highlands is subject to the Pahang State Authority. Additionally, the State Authority through the State Executive Council Bil. 25/2008 on 30th July 2008 has decided that the Director of Pahang Lands and Mines Department and District Officer of Cameron Highlands refuse all the new TOLs applications and only process the application for renewal of the existing TOLs (District and Land Office (DLO) Cameron Highlands 2017). Even though no new TOLs was issued, there is new land clearing for farming took place especially in Kampung Raja, Kuala Terla and Manson Valley (Ramasamy 2014). This probably due to poor enforcement and monitoring in the TOLs scheme lead to inappropriate agriculture practices where the TOLs can be rented, bequeathed or sold to others. In 2007, there are 1421 TOLs estimated out of 2500 to 2800 total farms in Cameron Highlands (i.e. some farmers may have more than one TOLs) where $83 \%$ of the farmers acquired the TOLs from the local government while $14 \%$ are land renting (Mazlan and Mumford 2005). The number has increased to 2543 TOLs holders in 2017 where 2041 (80\%) are licensed for agriculture purposes and concentrated in Hulu Telom sub-district (District and Land Office (DLO) Cameron Highlands 2017).

The High-Level Committee on Illegal Cultivation and Restoration of Cameron Highlands has decided to reconsider the application for TOLs submitted by the illegal farmers which were rejected by the Pahang government since 30 years back in which 217 ha of land involved (Chan 2017). The growing issues of illegal land clearing especially in the forest reserve area have alerted the federal government to take serious action through Malaysian National Security Council (NSC) under the Prime Minister's Department to monitor the illegal land clearing activities (Daim 2017).

Local District Plan or Rancangan Tempatan Daerah (RTD) in Cameron Highlands were developed by Cameron Highlands District Council for every 10 to 15 years. This is a physical planning that conveys in a form of land use proposal map by the local authority (Yusoff et al. 2014). The new RTD 2030 has been developed under the provisions of
Section 16 (1) of Act 172, with an aims to address the environmental issues in Cameron Highlands in return to develop it as sustainable highland tourism area (RTD 2018b). The opening and developing land illegally and beyond the permitted land use proposals are an infringement of Section 18 (1) of the Town and Country Planning Act 1976 (Act 172) stated that "no person shall use or develop any land or building unless according to the Local Plan" (District Council Cameron Highlands (DCCH) 2017).

Farm Accreditation Scheme or Skim Amalan Ladang Baik (SALM) was introduced in 2002 aimed to promote a Good Agriculture Practices (GAP) and to ensure the safety and quality of vegetables produce among the farmers. However, the scheme gained low participation from the local farmers as the majority of them have small-scale production and for domestic market only (Barrow et al. 2009; Radam et al. 2015). The GAP tends to skew more toward large-scale farms because of their bigger financial capacity and restricted with strict export requirements to the international market such as Singapore. The inability to adopt GAP, especially in conventional farming with limited facilities and always done in an open field, results in higher risk of pest infestation. Consequently, the application of pesticides is increasing to cater to the issues (Radam et al. 2015). Other factors such as low promotional campaigns, limited support and infrastructure, low financial capital capacity, and economic constraints also contribute to less participation.

A new scheme of the Malaysian Certificate Scheme for Good Agricultural Practice (MyGAP) was introduced in 2013 to replace SALM. Participation in this scheme is voluntary and the services provided for certification is free to the applicant (Department of Agriculture (DOA), Malaysia 2017). There are four main components in the MyGAP structure, namely, field inspection, observations, internal and external auditing and interviews with the farmers, and analysis of water harvested crops for pesticides and heavy metals residues. To receive this accreditation, farmers must be able to meet all these criteria (Radam et al. 2015):

1. Farm is a legal entity

2. Farm has soil inspection report

3. Soil and terrain suitable for the intended crop

4. Farms are located at an elevation $<1000 \mathrm{~m}$ above sea level (exception for farms operated before 2002)

5. Farms' practices compatible with soil conservation

6. Farms maintain up-to-date records of activities

7. Sewage or industrial sludge is not permitted to be used for fertilizers

8. Use of non-genetically modified planting materials for pest control

9. Pesticides used are legally registered under the Pesticides Board

10. Farm practices integrated pest management (IPM) 
11. Farm has proper storage area for fertilizers and pesticides

12. Farm workers must use personal protective clothing

13. Farm possesses a proper waste disposal plan

14. Farm practices the good harvesting management system

15. Farm employs legal workers

16. Pesticide residues on farm produce are reduced

17. Heavy metal content must be below permissible levels

Table 2 highlighted the differences between GAP and conventional farming systems in Cameron Highlands. Most of the farmers do not have formal education in good agriculture practice and farm management as only $1 \%$ of the 2200 farmers are seeking training from the local Department of Agriculture (DOA) (Mazlan and Mumford 2005). Nevertheless, there are some limitations of the scheme such as poor monitoring practices at the production level, no laboratory established for monitoring the quality of produces, and no institution empowered to verify the GAP and SALM certificate at the farm level and to raise global-scale recognition to promote Malaysian vegetable products (Radam et al. 2015).

Another scheme introduced by the Department of Agriculture is the Malaysian Organic Scheme Certification (MyORGANIC). However, there are only 13 certified organic farmers out of 2200 farmers in Cameron Highlands. Barrow et al. (2009) have highlighted that the lack of capital restricted the shift toward organic farming as most of the farms are to serve for smaller scale production. Since they are doing the farming on the TOL land, it is hard for them to get a financial support and loan from the banks. The temporary status of ownership on the lands and burdensome protocols for renewing the license has demotivated them from adopting organic farming. Moreover, the organic farming works need to be done manually and require intensive labor and manpower. Due to labor shortages, this has discouraged them from adopting this option. Lack of training and extension service by the DOA and other government agencies as well as less marketing of the organic-based products also contribute to less participation in organic farming. Most of the people were unaware of the importance of consuming organic-based products and the prices of these products which are higher than the conventional farming products have contributed to the difficulties of selling these products. Expensiveness and complexity of certification process, which roughly took 23 years, and providing no incentives also influence the disappointment of this program (Tiraieyari et al. 2014)

\section{Past and related studies on river water quality status in Cameron Highlands}

This section highlighted past studies with regards to water pollution in Cameron Highlands. Most of the studies found that the parameters such as temperature, electrical conductivity (EC), total dissolved solids (TDS), total suspended solids (TSS), nutrient enrichment, and biochemical oxygen demand (BOD) increased as the river water flowing down the stream as a result of contaminant accumulation, magnification, and sediment transport (Aminu et al. 2014; Rasul et al. 2015; Tan and Beh 2016).

The downstream after Brinchang was reported of excessive EC, TDS, and TSS (Eisakhani and Malakahmad 2009; Rasul et al. 2015). This was related to extensive

Table 2 The differences between agriculture farming system in Cameron Highlands (Tiraieyari et al. 2014; Radam et al. 2015)

\begin{tabular}{|c|c|c|}
\hline GAP farming system & Characteristics & Conventional farming system \\
\hline Large (> 10 ha) & Area of farm & Small (<5 ha) \\
\hline $\begin{array}{l}\text { Big-scale production for domestic and international } \\
\text { market } \\
\text { Better marker access } \\
\text { Priority as supplier in the local hypermarkets }\end{array}$ & Production scale & Small-scale only for domestic market \\
\hline $\begin{array}{l}\text { High } \\
\text { Maintenance cost (e.g., plastic rain shelter } \\
\text { New technologies, infrastructure and facilities } \\
\text { Fertilizers cost }\end{array}$ & Production cost & Low \\
\hline Relatively high (only due to large farm area) & Labor cost & High \\
\hline $\begin{array}{l}\text { Low (use natural water supply from upper } \\
\text { catchment) }\end{array}$ & Irrigation cost & Low (use natural water supply from upper catchment) \\
\hline High & Yield per plant (kg) & Low \\
\hline $\begin{array}{l}\text { High (due to its better appearance, size and quality) } \\
\text { E.g., tomato (USD 2.00) }\end{array}$ & Market price & $\begin{array}{l}\text { Low } \\
\text { E.g., tomato (USD 1.00) }\end{array}$ \\
\hline $\begin{array}{l}\text { Longer (cultivates are grown in a protected } \\
\text { environment) }\end{array}$ & Crop production cycle & $\begin{array}{l}\text { Shorter (cultivates directly exposed to external factor such as wind, } \\
\text { pest, rain, etc.) }\end{array}$ \\
\hline $\begin{array}{l}\text { Plastic rain shelter } \\
\text { Fertigation } \\
\text { Hydroponics }\end{array}$ & Practices & Open-field farming \\
\hline
\end{tabular}


farming and residential areas (Rasul et al. 2015). The EC, TDS, and TSS values increased significantly in wet season or high water flow which indicated that more soil erosion and runoff that bring contaminants and increase nutrient loss in water bodies occur during rain. The use of alkaline detergent and wastewater from residential and small-scale industrial areas had increased the river water $\mathrm{pH}$ at Brinchang (Eisakhani and Malakahmad 2009). The temperature of water increases proportionally as it flowed downstream as the concentration of nutrients and EC increases (Rasul et al. 2015). TDS was highly recorded in the area with extensive plantation and during the wet season (Khalik et al. 2013a).

Water flow does affect the water quality as the quantities of contaminants entering the water body increased during high water flow due to precipitation especially in the form of an agriculture runoff. Previous studies have reported decreased in river WQI in the wet season especially after heavy rainfall (Eisakhani and Malakahmad 2009; Gasim et al. 2009; Khalik et al. 2013a; Aminu et al. 2014). The secondary data from the Department of Environment on water quality and streamflow monitoring during average water flow (AWF) and high water flow (HWF) between 74 stations in Telom to Bertam River and its tributaries also have shown water quality degradation as the stream flow of the river increases due to a sudden increase in TSS particularly triggered after a heavy rainfall (Gasim et al. 2009). Besides, as the surface soil that retains the nutrients is introduced into water bodies, it releases a significant amount of nutrients that can cause eutrophication. Eisakhani and Malakahmad (2009) have reported excessive nitrogen and phosphorus content exceeding the WHO recommended value in both average and high water flow in Cameron Highland river. Both water quality studies by Khalik et al. (Khalik et al. 2013a, 2013b), indicated that the mean value of phosphate exceeds the recommended values by the Malaysia National Drinking Water Quality Standard (NDWQS) and WHO in this area. Rasul et al. (2015) have determined the highest total nitrogen (TN), total phosphorus (TP), ammoniacal-nitrogen $\left(\mathrm{NH}_{3}-\mathrm{N}\right)$, nitrate-nitrogen $\left(\mathrm{NO}_{3}-\mathrm{N}\right)$, and phosphate-phosphorus $\left(\mathrm{PO}_{4}-\mathrm{P}\right)$ values which were found in two sampling points at the Bertam downstream where farming activities are noticeable and intensive. In addition, high number of Escherichia coli (E. coli) (more than $200 \mathrm{MPN} / 100 \mathrm{ml}$ ) was detected in this area which was related to the untreated domestic wastewater and chicken manure used as fertilizers in agricultural activities discharged in the water bodies (Eisakhani and Malakahmad 2009). In March 2012, Kuala Terla Water Treatment Plant (WTP) was temporarily shut down because of illegal farming and the use of excessive pesticides and fertilizers that caused hundreds of fishes in the stream to die (Sinar Harian 2012; Utusan Malaysia 2012). Tables 3 and 4 summarizes the findings from previous studies on water quality of the river network in Cameron Highlands.

The residues of pesticides also were detected in the water. Abdullah et al. (2015a) have detected OCPs residues: methoxychlor $(0.06 \mu \mathrm{g} / \mathrm{L})$, endrin ketone $(0.63 \mu \mathrm{g} / \mathrm{L})$ , and 4,4'-DDE $(0.02 \mu \mathrm{G} / \mathrm{L})$ in the surface water of Bertam River and Terla River. An analysis of tap water in Brinchang town also found traces of these OCP compounds.

\section{Relationship between land use change, agriculture practices, and agro-tourism with highland river water quality}

Approximately, $66 \%$ of the land in Cameron Highlands have gradients more than $20^{\circ}$ that can trigger the soil erosion and landslides (Aminuddin et al. 2001; Gasim et al. 2010; Khairulmaini and Fauza 2010; Kunasekaran et al. 2011; Tan and Mokhtar 2011; Mohd Ariffin et al. 2014; Rendana et al. 2015; Rozimah and Khairulmaini 2016). Sandy soil and high-average annual rainfall increase the movement of soil (Aminuddin et al. 2001). In addition, the weathering of granite in Cameron Highlands has triggered the development of very shallow soils on the slopes (Khairulmaini and Fauza 2010). The limitation on flat land available for development and agriculture purpose has caused land clearing on the steep land to meet the demand (Weebers and Idris 2016). Thus, any disturbances that potentially could alter the dynamic equilibrium of the river system (upstream water catchment) in Cameron Highlands will definitely give significant influence on the dynamic and performance of the river system downstream.

The main issues of river pollution in Cameron Highlands are sedimentation and siltation (Gasim et al. 2009; Gasim et al. 2010; Khairulmaini and Fauza 2010). It can be seen through the physical characterization of the river water which is brown or milk-tea in color. As the poor agricultural practices, construction for urbanization, overgrazing, land clearing, and deforestation continuously intensify take place in the highland areas, soil erosion and landslides will cause aquatic imbalance, deterioration of river water quality, and reservoir capacity (Toriman et al. 2010; Tan and Mokhtar 2011). Onsite impact of soil erosion such as reducing the soil quality as the most fertile upper layer gets lost easily while off-site impact caused increased water turbidity, nutrient enrichment, flood, and poor water quality (Sholagberu et al. 2016; Barrow et al. 2009; Khairulmaini and Fauza 2010). This also can reduce the performance and capacity of hydroelectric dams which serve as the energy supply for the western parts of Peninsular Malaysia. The increment of sediment load in the rivers greatly influences by the land use changes within the water catchment areas (Toriman et al. 2010).

Previous studies have identified that sediment loads in the rivers of Asia have been rapidly increasing due to the 
Table 3 Comparison of particular water quality parameters' mean values obtained from various studies on rivers and tributaries in Cameron Highlands

\begin{tabular}{|c|c|c|c|c|c|c|c|c|c|c|c|c|c|c|}
\hline No. & $\begin{array}{l}\text { References/parameters (mean } \\
\text { values) }\end{array}$ & $\mathrm{pH}$ & $\begin{array}{l}E C \\
\mu S / \mathrm{cm}\end{array}$ & $\begin{array}{l}\mathrm{DO} \\
(\mathrm{mg} / \mathrm{l})\end{array}$ & $\begin{array}{l}\text { TDS } \\
(\mathrm{mg} / \mathrm{l})\end{array}$ & $\begin{array}{l}\text { Salinity } \\
\text { (ppt) }\end{array}$ & $\begin{array}{l}\text { Turbidity } \\
\text { (NTU) }\end{array}$ & $\begin{array}{l}\mathrm{BOD} \\
(\mathrm{mg} / \mathrm{l})\end{array}$ & $\begin{array}{l}\mathrm{COD} \\
(\mathrm{mg} / \mathrm{l})\end{array}$ & $\begin{array}{l}\mathrm{NH}_{3}-\mathrm{N} \\
(\mathrm{mg} / \mathrm{l})\end{array}$ & $\begin{array}{l}\text { TSS } \\
(\mathrm{mg} / \mathrm{l})\end{array}$ & $\begin{array}{l}\text { TN } \\
(\mathrm{mg} / \mathrm{L})\end{array}$ & $\begin{array}{l}\text { TP } \\
(\mathrm{mg} / \mathrm{L})\end{array}$ & WQI \\
\hline 1 & $\begin{array}{l}\text { Eisakhani and Malakahmad } \\
2009^{\mathrm{a}}\end{array}$ & 6.90 & 52.11 & - & 23.60 & - & - & - & 13.40 & - & 16.01 & 1.70 & 0.22 & - \\
\hline 2 & Riduan et al. 2009 & 7.30 & 49.00 & 3.19 & 0.030 & - & 603.00 & - & - & - & - & - & - & - \\
\hline 3 & Saadati et al. 2012 & - & 67.90 & - & 13.20 & 0.03 & 170.75 & - & - & - & 480.00 & - & - & - \\
\hline 4 & Khalik et al. 2013a & 6.54 & 58.33 & 6.31 & 43.33 & 0.01 & - & 2.64 & 16.67 & 0.25 & 15.08 & 1.13 & 0.88 & $\begin{array}{l}78.00 \\
\text { (class II) }\end{array}$ \\
\hline 5 & Khalik et al. 2013b & 6.52 & 51.83 & 4.83 & 38.40 & - & - & - & - & 0.14 & - & - & 1.60 & - \\
\hline 6 & Khalik and Abdullah 2013 & 7.40 & 95.69 & 9.28 & 40.00 & 0.02 & - & - & - & - & - & - & - & - \\
\hline 7 & Al-Nafiey et al. 2014 & 7.65 & 50.07 & - & - & - & - & - & - & - & - & - & - & - \\
\hline 8 & Jamil et al. $2014^{a}$ & - & - & - & - & - & - & - & - & - & - & - & - & $\begin{array}{l}77.05 \\
\text { (class II) }\end{array}$ \\
\hline 9 & Abdullah et al. 2015a & 6.35 & 54.98 & 8.48 & 35.86 & 0.02 & - & - & - & - & - & - & - & - \\
\hline 10 & Aminu et al. $2014^{\mathrm{a}}$ & 8.12 & - & 8.33 & - & - & - & 1.76 & 13.00 & 0.80 & 85.05 & - & - & $\begin{array}{l}62.41 \\
\text { (class III) }\end{array}$ \\
\hline 11 & Rasul et al. 2015 & 6.87 & 68.80 & 7.08 & 47.15 & - & 88.63 & 7.79 & 20.55 & 0.95 & 136.05 & 3.28 & 1.16 & - \\
\hline 12 & Tan and Beh 2016 & 6.19 & - & 6.84 & - & - & - & 2.90 & 27.42 & 0.23 & 0.05 & - & - & $\begin{array}{l}82.92 \\
\text { (class II) }\end{array}$ \\
\hline
\end{tabular}

${ }^{\mathrm{a} D r y}$ season/AWF (average water flow)

increase rate of inland soil erosion mainly caused by growing population. This had caused a negative impact in terms of reducing soil fertility, siltation in reservoirs, risk of flash or mud floods in lowlands (Diyabalanage et al. 2017). Slopes are also one of the main influencing factors in soil erosion and the hill slopes with the percentage of more than $32 \%$ is highly vulnerable to soil erosion (Lee et al. 2010; Diyabalanage et al. 2017). Poor soil management against soil erosion and heavy fertilizers application are the main problems of unsustainable agriculture practices in the highland areas of South Korea (Lee et al. 2010).

Precipitation does influence the rate of runoff, nutrient loss, and soil erosion into the catchment area especially during and in the post-monsoon period (Eisakhani et al. 2011; Sholagberu et al. 2016). High precipitation increases the rain-splash and runoff detachment on the hill slopes resulting in a high wash of load into the rivers (Sholagberu et al. 2016; Diyabalanage et al. 2017). High precipitation in

Table 4 Comparison of heavy metals concentration in water (mg/L) of rivers and tributaries and in agricultural soils (mg/kg) of selected farms in Cameron Highlands

\begin{tabular}{|c|c|c|c|c|c|c|c|c|c|c|c|c|c|c|c|c|c|c|}
\hline \multirow[b]{2}{*}{ No. } & \multirow[b]{2}{*}{$\begin{array}{l}\text { References/parameters } \\
\text { (mean) }\end{array}$} & \multirow[b]{2}{*}{ Sample } & \multirow[b]{2}{*}{$\begin{array}{l}\mathrm{Rn}^{222} \\
(\mathrm{~Bq} / \mathrm{L})\end{array}$} & \multirow[b]{2}{*}{$\mathrm{Al}$} & \multirow[b]{2}{*}{ As } & \multicolumn{13}{|c|}{ Total heavy metal concentration $(\mathrm{mg} / \mathrm{kg}) /(\mathrm{mg} / \mathrm{L})$} \\
\hline & & & & & & $\overline{\mathrm{Ca}}$ & $\mathrm{Cd}$ & Co & $\mathrm{Cr}$ & $\mathrm{Cu}$ & $\mathrm{Fe}$ & K & Mg & $\mathrm{Mn}$ & $\mathrm{Na}$ & $\mathrm{Ni}$ & $\mathrm{Pb}$ & $\mathrm{Zn}$ \\
\hline \multirow[t]{4}{*}{1} & Khairiah et al. 2006 & Soil & & & & & & & & & & & & & & & & \\
\hline & Brinchang & & - & - & - & - & ${ }^{\mathrm{a} B D L}$ & - & 18 & 93 & 402 & - & - & 921 & - & - & ${ }^{\mathrm{a} B D L}$ & 87.6 \\
\hline & Ringlet & & & & & & 0.9 & & 10 & 117 & 322 & & & 885 & & & ${ }^{\mathrm{a} B D L}$ & 90.2 \\
\hline & Tanah Rata & & & & & & 0.1 & & 12 & 59 & 469 & & & 355 & & & ${ }^{\mathrm{a} B D L}$ & 38.1 \\
\hline \multirow[t]{4}{*}{2} & Hamzah et al. 2011 & Soil & & & & & & & & & & & & & & & & \\
\hline & Bharat & & - & - & - & - & - & - & - & - & 3252 & - & - & - & - & - & - & 250 \\
\hline & Kg. Raja & & & & & & & & & & 4337 & & & & & & & 253 \\
\hline & Lembah Bertam & & & & & & & & & & 4100 & & & & & & & 246 \\
\hline 3 & $\begin{array}{l}\text { Khalik and Abdullah } \\
2013\end{array}$ & Water & - & 1.30 & 0.001 & 4.8 & 0.002 & - & - & 0.08 & 0.60 & 1.90 & 0.80 & 0.012 & 2.80 & - & 0.005 & 0.008 \\
\hline 4 & Al-Nafiey et al. 2014 & Water & 0.25 & - & - & - & 0.009 & 0.009 & - & 0.08 & - & - & - & - & - & 0.043 & 0.07 & 0.08 \\
\hline 5 & Ismail et al. 2017 & Water & - & - & - & - & - & - & $\begin{array}{l}{ }^{\mathrm{a} B D L-} \\
0.02\end{array}$ & $\begin{array}{l}{ }^{\mathrm{a}} \mathrm{BDL}- \\
0.02\end{array}$ & - & - & - & - & - & - & $\begin{array}{l}{ }^{\mathrm{a} B D L-} \\
0.03\end{array}$ & $\begin{array}{l}{ }^{\mathrm{a} B D L-} \\
0.11\end{array}$ \\
\hline
\end{tabular}


Cameron Highlands increases the erodibility rate of the slope soil (Khairulmaini and Fauza 2010). The erosive power increased as the amount of kinetic energy and the intensity of rainfall increased especially during the wet season (January-April and August-November) (Sholagberu et al. 2016). Organochlorine pesticides (DDT and $\mathrm{HCH}$ ) were more concentrated in sediment and water sampled during the wet season as the frequency of pesticides application increases because of the tendency of the pesticides to wash off easily during raining, hence increase the pest infestation on crops (Mazlan and Mumford 2005; Saadati et al. 2012; Abdullah et al. 2015a, 2015b). Dilution in the downstream causes lower concentrations of pesticides detected in water (Abdullah et al. 2015a). The increasing trend of mean discharge of rivers are caused by increasing runoff during precipitation due to decreased infiltration rate into the soil caused by land clearing and deforestation (Gasim et al. 2010). Sampling locations that are located nearby agricultural activities and tourist attractions are recorded of having a higher concentration of contaminants in the water and sediments compared with sampling locations far from point sources pollution (Saadati et al. 2012). Many tributaries that join with the main rivers also affect the concentration of contaminants (Abdullah et al. 2015a). Table 5 below shows the literature on land use/land changes in highlands areas of others countries worldwide, see Appendix for more details.

\section{Study recommendations}

Many efforts have been made to address the land use changes in Cameron Highlands. For example, intensive agriculture census throughout farming areas in Cameron Highlands was conducted by the DOA in 2017. This systematic mapping was done through Geographic Information System (GIS) to identify illegal farms and facilitate the continuous and periodic monitoring activities in the future. The authority is also actively conducting an inspection and law enforcement to combat illegal land encroachment activities in Cameron Highlands. This operation is led by the NSC and has been in the fourth year now since started in 2014. This is a continuous effort done by the authority till present (Kannan 2018). The implementation of this operation is in line with the conservation efforts done to reduce the effect of land use activities in Cameron Highlands. A flood mitigation project in Bertam Valley also has been implemented in 2015 which serves as an effective water catchment area to avoid soil erosion that triggers flood and mudslide especially during a heavy downpour (Maharan 2015).

Many more strategies and proposals have been suggested in the RTD 2030 to address land use changes in this area. For instance, a strategy was designed to improve land use planning, disaster risk management, and the nature in Cameron Highland (RTD 2018b). Planning also was done focusing on to produce a sustainable highland tourism activity through sustainable agricultural management. This particularly in addressing sustainable development with the main idea is to restore the glory of Cameron Highlands as a prosperous and sustainable highland area. The planning is also focusing on effective governance in this area.

Many efforts and strategies have been outlined. However, challenging hilly geographical factor and topography may be a limitation for a comprehensive strategic action plan. Nevertheless, ongoing efforts should be continued such as more efficient and strict law enforcement, frequent and continuous monitoring for illegal land clearing for agriculture activities, continuous monitoring of sustainable and good agriculture practices, and civic awareness among local communities especially farmers to dispose organic agricultural wastes and pesticide bottles to proper places and not into the river. Surely, all these efforts involve the two-way participation from authorities as well as the local community. This is important in order to avoid any risk of natural disasters that could lead to life threatening and high-cost overhaul work after the disaster and also may affect the economy of Cameron Highlands which is generated mainly by agriculture and tourism. The efforts undertaken by the government should be necessary and crucial to curbing the environmental issues. However, it should be noted that these efforts involve short-, medium-, and long-term plans and definitely cost millions of Ringgit with high-capital investment. Therefore, every strategic plan should be implemented in detail, transparent, and effective to achieve satisfactory results.

\section{Conclusions}

Rampant land clearing for agriculture and urbanization purposes have shown a negative impact on the fragile highlands ecosystem. Massive forest shrinking to make way for large-scale land clearing was reported. Studies provide evidence that land use change, unplanned development, and unsustainable agricultural activities have directly and indirectly deteriorated the quality of river water system in the Cameron Highlands. Improvement of the existing laws and regulations enforcement is important to control the effect of intensive agriculture activity to the natural beauty of the highland area and at the same time able to secure benefit and productivity of farmers. Highland natural areas provide important ecological services to humans and the environment. Environmental conservation is crucial to ensure the sustainability of an area to avoid loss of ecological resources. The wrecking of the natural forests has its repercussion and is apparent with the numbers of tragedies that occur over time in Cameron Highlands such as mud flood, soil erosion, landslide, water treatment plant pollution, and rise in local temperature which are some classic examples of unsustainable agriculture development. This is to reduce the human-environment conflict and achieve reciprocal benefits between these two entities. 


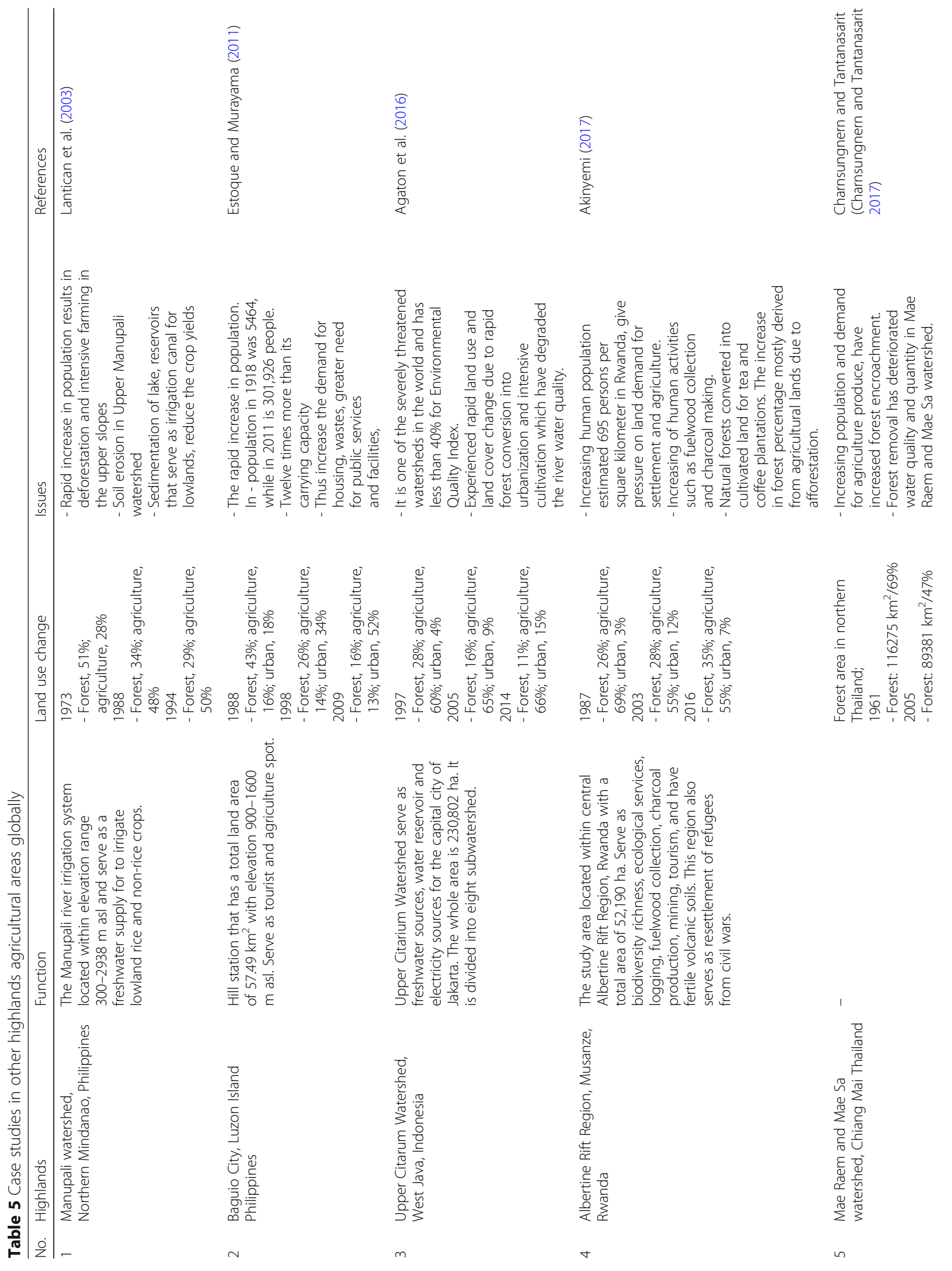




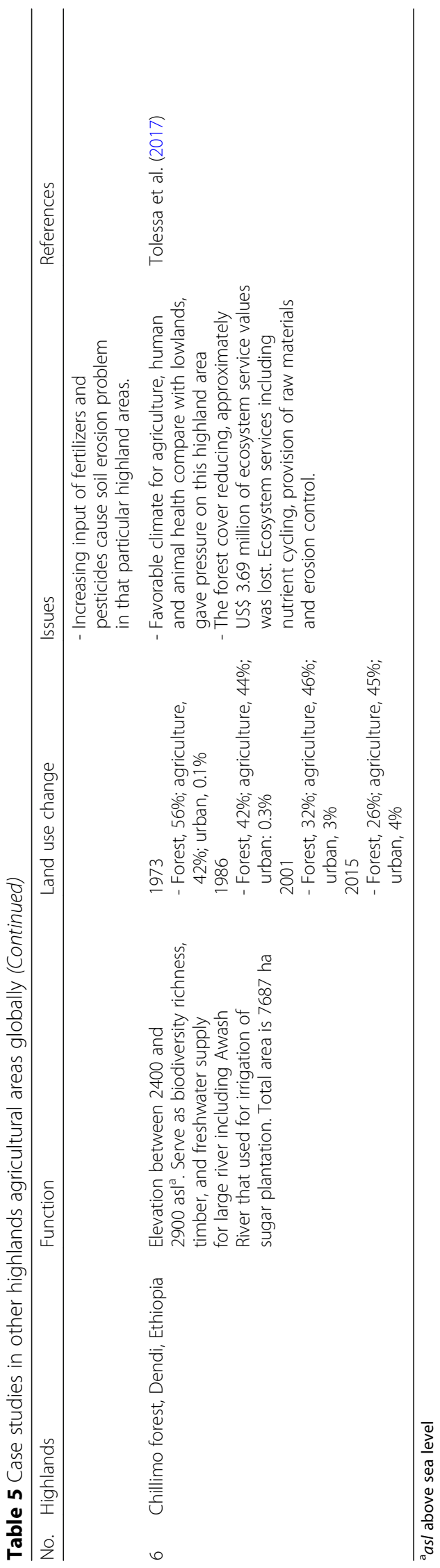




\section{Appendix}

Table 6 Data for land use and land change studies (including agriculture practices, agro-tourism, and policy and management)

\begin{tabular}{|c|c|c|c|}
\hline Author & Study years & Region & Method used \\
\hline 1. Agaton et al. (2016) & 1997-2014 & West Java, Indonesia & Landsat image, ERDAS IMAGINE, and ArcGIS \\
\hline 2. Akinyemi (2017) & $1987-2016$ & Albertine rift, Musanze Rwanda & Landsat image and ancillary data \\
\hline 3. Aminu et al. (2014) & 2014 & Cameron Highlands & $\begin{array}{l}\text { GIS and Analytical Network Process of Multi-Criteria } \\
\text { Evaluation }\end{array}$ \\
\hline 4. Aminuddin et al. (2005) & 2005 & Cameron Highlands & Experimental plots \\
\hline 5. Aminuddin et al. (2001) & 2001 & Cameron Highlands & Experimental plots \\
\hline 6. Barrow et al. (2009) & $2002-2007$ & Cameron Highlands & Questionnaires \\
\hline 7. Chan (2017) & 2017 & Cameron Highlands & Press article \\
\hline $\begin{array}{l}\text { 8. } \\
\text { Charnsungnern and Tantanasarit (2017) }\end{array}$ & $1961-2005$ & Chiang Mai, Thailand & $\begin{array}{l}\text { Aerial photograph, topographic map, land use map and } \\
\text { ArcGIS }\end{array}$ \\
\hline 9. Daim (2017) & 2017 & Cameron Highlands & Press article \\
\hline $\begin{array}{l}\text { 10. Department of Agriculture (DOA), } \\
\text { Malaysia (2017) }\end{array}$ & 2017 & Cameron Highlands & Report \\
\hline $\begin{array}{l}\text { 11. District and Land Office (DLO) } \\
\text { Cameron Highlands (2017) }\end{array}$ & 2017 & Cameron Highlands & Report \\
\hline $\begin{array}{l}\text { 12. District Council Cameron Highlands } \\
\text { (DCCH) (2017) }\end{array}$ & 2017 & Cameron Highlands & report \\
\hline 13. Diyabalanage et al. (2017) & 1994-2005 & Mahaweli Catchment, Sri Lanka & Land use map, hydrological data, and sediment yield \\
\hline 14. Eisakhani et al. (2011) & $2006-2010$ & Cameron Highlands & Land use data and GIS \\
\hline 15. Eisakhani et al. (2009) & $2006-2010$ & Cameron Highlands & Land use data and ArcView GIS \\
\hline 16. Estoque and Murayama (2011) & 1988-2009 & $\begin{array}{l}\text { Baguio city, Luzon Island } \\
\text { Philippines }\end{array}$ & Landsat image, land use map, and ERDAS IMAGINE \\
\hline 17. Gasim et al. (2010) & 1984-2002 & Cameron Highlands & Land use map and hydrological data \\
\hline 18. Hamdan et al. (2014) & 2013 & Cameron Highlands & Qualitative research \\
\hline 19. Haron et al. (2014) & 2014 & Cameron Highlands & Land use map and GIS \\
\hline 20. Ismail et al. (2012) & $2000-2010$ & Cameron Highlands & SPOT5, ERDAS IMAGINE, and ArcGIS \\
\hline 21. Kannan (2018) & 2018 & Cameron Highlands & Press article \\
\hline 22. Khairulmaini and Fauza (2010) & 2010 & Cameron Highlands & Review article \\
\hline 23. Kunasekaran et al. (2011) & 2011 & Cameron Highlands & Questionnaires \\
\hline 24. Lantican et al. (2003) & 1973-1994 & $\begin{array}{l}\text { Bukidnon, Mindanao } \\
\text { Philippines }\end{array}$ & $\begin{array}{l}\text { Landsat image, SPOT HRV, land use map, secondary data of } \\
\text { agriculture (yield, cost of production, amount of silt removed } \\
\text { from irrigation canal etc.) }\end{array}$ \\
\hline 25. Lee et al. (2010) & 2010 & Baegdu, South Korea & Soil survey map and questionnaires \\
\hline 26. Maharan (2015) & 2015 & Cameron Highlands & Press article \\
\hline 27. Mansor et al. (2015) & 2015 & Cameron Highlands & Questionnaires \\
\hline 28. Mazlan and Mumford (2005) & 2002 & Cameron Highlands & Questionnaires \\
\hline 29. Mispan et al. (2015) & 2015 & Cameron Highlands & Questionnaires \\
\hline 30. Mohd Ariffin et al. (2014) & 2014 & Cameron Highlands & Questionnaires (pilot test) \\
\hline 31. Oliver et al. (2017) & 2017 & Cameron Highlands & Questionnaires \\
\hline 32. Radam et al. (2015) & 2007 & Cameron Highlands & Questionnaires \\
\hline 33. Raj (2002) & 2002 & Cameron Highlands & Keynote paper \\
\hline 34. Ramasamy (2014) & 2014 & Cameron Highlands & Press article \\
\hline 35. RTD 2003 (RTD 2018a) & 2003 & Cameron Highlands & Cameron Highlands District Local Plan \\
\hline 36. RTD 2030 (RTD 2018b) & 2015 & Cameron Highlands & Cameron Highlands District Local Plan \\
\hline
\end{tabular}


Table 6 Data for land use and land change studies (including agriculture practices, agro-tourism, and policy and management) (Continued)

\begin{tabular}{llll}
\hline Author & Study years & Region & Method used \\
\hline 37. Rendana et al. (2015) & $1997-2014$ & Cameron Highlands & Landsat image and ArcGIS \\
38. Roozitalab et al. (2013) & 2013 & Iran, Morocco, and Turkey & Working paper \\
39. Rozimah and Khairulmaini (2016) & $1996-2010$ & Cameron Highlands & Land use map and GIS \\
40. Sholagberu et al. (2016) & $1995-2003$ & Cameron Highlands & USLE/RUSLE \\
41. Sinar Harian (2012) & 2012 & Cameron Highlands & Press article \\
42. Singh et al. (2011) & 2011 & - & Review article \\
43. Sonter et al. (2017) & 2017 & - & Review article \\
44. Tan and Mokhtar (2011) & 2008 & Cameron Highlands & Questionnaires \\
45. Tiraieyari et al. (2014) & 2013 & Cameron Highlands & Questionnaires \\
46. Tolessa et al. (2017) & $1973-2015$ & Dendi, Ethiopia & Landsat image, Land use map, ERDAS IMAGINE, and ArcGIS \\
47. Toriman et al. (2010) & 2010 & Cameron Highlands & Hydrographic survey and riverbed sediment, physical \\
& & & characteristics of the rivers, meteorological and hydrological \\
& 2012 & Camerand InfoWork RS & Press article \\
48. Utusan Malaysia (2012) & $1884-2016$ & Cameron Highlands & Review (content analysis) \\
49. Weebers and Idris (2016) & 2014 & Selangor, Malaysia & Review article \\
50. Yusoff et al. (2014) & $2001-2010$ & Cameron Highlands & Satellite images, IKONOS, and SPOT5 \\
51. Zin and Ahmad (2014) & & &
\end{tabular}

Table 7 Data for river water quality and soil study in Cameron Highlands

\begin{tabular}{lll}
\hline Author & Study years & Method used \\
\hline 1. Abdullah et al. (2015a) & 2014 & Field measurement and lab analysis \\
2. Abdullah et al. (2015b) & 2011 & Field measurement and lab analysis. \\
3. Al-Nafiey et al. (2014) & 2014 & Field measurement and lab analysis \\
4. Eisakhani and Malakahmad (2009) & 2009 & Field measurement and lab analysis. \\
5. Farina et al. (2016) & 2016 & Lab analysis \\
6. Gasim et al. (2009) & 2002 & Secondary data from Dept. of Environment \\
7. Hamzah et al. (2011) & 2011 & Lab analysis \\
8. Ismail et al. (2017) & 2017 & Field measurement and lab analysis. \\
9. Jamil et al. (2014) & 2012 & Field measurement and lab analysis. \\
10. Khairiah et al. (2006) & 2006 & Lab analysis \\
11. Khalik et al. (2013a) & 2012 & Field measurement and lab analysis. \\
12. Khalik et al. (2013b) & 2012 & Field measurement and lab analysis. \\
13. Khalik and Abdullah (2013) & 2013 & Field measurement and lab analysis. \\
14. Rasul et al. (2015) & 2014 & Field measurement and lab analysis. \\
15. Riduan et al. (2009) & 2009 & Field measurement and lab analysis. \\
16. Saadati et al. (2012) & 2011 & Field measurement and lab analysis. \\
17. Tan and Beh (2016) & 2016 & Field measurement and lab analysis \\
\hline
\end{tabular}




\section{Abbreviations}

Al: Aluminum; As: Arsenic; ASL: Above sea level; AWF: Average water flow: BDL: Below detection limit; BOD: Biochemical oxygen demand; Ca: Calcium; Cd: Cadmium; Co: Cobalt; COD: Chemical oxygen demand; Cr: Chromium; Cu: Copper; DO: Dissolved oxygen; DOA: Department of Agriculture; EC: Electrical conductivity; EIQ: Environmental impact quotient; Fe: Iron; GAP: Good Agriculture Practices; GIS: Geographic Information System; HWF: High water flow; IPM: Integrated Pest Management; K: Potassium; LULC: Land use/land change; Mg: Magnesium; Mn: Manganese; MyGAP: Malaysian Certificate Scheme for Good Agriculture Practices; MyORGANIC: Malaysian Organic Scheme Certificate; Na: Sodium; NDWQS: Malaysia National Drinking Water Quality Standard; $\mathrm{NH}_{3}$ $\mathrm{N}$ : Ammoniacal-nitrogen; Ni: Nickel; $\mathrm{NO}_{3}-\mathrm{N}$ : Nitrate-nitrogen; NSC: Malaysian National Security Council; OCPs: Organochlorine pesticides; $\mathrm{Pb}$ : Lead; $\mathrm{PO}_{4}$ P: Phosphate-phosphorus; Rn: Radon; RTD: Rancangan Tempatan Daerah/ Local Development Plan; SALM: Skim Amalan Ladang Baik; TDS: Total dissolved solids; TN: Total nitrogen; TOLs: Temporary Occupation Licenses; TP: Total phosphorus; TSS: Total suspended solids; WHO: World Health Organization; WQI: Water quality index; WTP: Water treatment plant; Zn: Zinc

\section{Acknowledgements}

The additional information and data on the study area are provided by local authorities including Department of Agriculture Cameron Highlands, Department of Irrigation and Drainage Cameron Highlands, District Council Cameron Highlands, and District and Land Office Cameron Highlands. The authors would like to thank them for supporting this work. All opinions expressed in this paper are the authors' and do not necessarily reflect the policies and views of the local authorities. The reviewers' comments and suggestion have help to improve an earlier version of the manuscript.

\section{Funding}

Financial support for this study was provided by the National Hydraulic Research Institute of Malaysia (NAHRIM) and Sumitomo Foundation Research Grant (Reg. No. 168401-41).

\section{Availability of data and materials}

All data generated and analyzed during this study are included in this published article.

\section{Authors' contributions}

AR conceived and designed the manuscript. SNSI checked and corrected the content. SA contributed the analysis tools and checked the final draft. SMP and EZA checked the final draft. All authors have read and approved the final manuscript.

\section{Ethics approval and consent to participate}

Not applicable.

\section{Competing interests}

The authors declare that they have no competing interests.

\section{Publisher's Note}

Springer Nature remains neutral with regard to jurisdictional claims in published maps and institutional affiliations.

\footnotetext{
Author details

${ }^{1}$ Department of Environmental and Occupational Health, Faculty of Medicine and Health Sciences, Universiti Putra Malaysia, 43400 Serdang, Selangor, Malaysia. ${ }^{2}$ River Basin Research Centre, National Hydraulic Research Institute of Malaysia (NAHRIM), Lot 5377, Jalan Putra Permai, 43300 Seri Kembangan, Selangor, Malaysia.
}

Received: 5 January 2018 Accepted: 14 April 2018 Published online: 05 May 2018

\section{References}

Abdullah MP, Abd Aziz YF, Othman MR, Wan Mohd Khalik WMA (2015a) Organochlorine pesticides residue level in surface water of Cameron Highlands, Malaysia. Iran J Energy Environ 6(2):141-146. https://doi.org/10. 5829/idosi.ijee.2015.06.02.10
Abdullah MP, Saadati N, Wan Mohd Khalik WMA, Zakaria Z (2015b) Pattern recognition of the presence and distribution of organochlorine pesticides in sediment of Cameron Highlands, Malaysia. Malays J Anal Sci 19(4):692-706

Agaton M, Setiawan Y, Effendi H (2016) Land use/land cover change detection in an urban watershed: a case study of Upper Citarum Watershed, West Java Province, Indonesia. Procedia Environ Sci 33:654-660

Akinyemi FO (2017) Land change in the Central Albertine Rift: insights from analysis and mapping of land use-land cover change in north-western Rwanda. Appl Geogr 87:127-138

Al-Nafiey M, Jaafar MS, Bauk S (2014) Measuring radon concentration and toxic elements in the irrigation water of the agricultural areas in Cameron Highlands, Malaysia. Sains Malaysiana 43(2):227-231

Aminu M, Matori AN, Yusof KW (2014) A spatial decision support system (SDSS) for sustainable tourism planning in Cameron Highlands, Malaysia. IOP Conference Series. Earth Environ Sci 18:1-8. https://doi.org/10.1088/1755-1315/18/1/012139

Aminuddin BY, Ghulan MH, Wan Abdullah WY, Zulkefli M, Salama RB (2005). Sustainability of current agricultural practices in the Cameron Highlands, Malaysia. Water, air and soil pollution: Focus 5:89-101

Aminuddin BY, Wan Abdullah WY, Cheah UB, Ghulam MH, Zulkefli M, Salama RB (2001) Impact of intensive highland agriculture on the ecosystem. J Trop Agric Food Sci 29(1):69-76

Barrow CJ, Chan NW, Masron T (2009) Issues and challenges of sustainable agriculture in the Cameron Highlands. Malays J Environ Manag 2:89-114

Chan LL (2017) Farmers get second chance. The Star Retrieved from https:// www.thestar.com.my/metro/community/2017/05/23/farmers-get-secondchance-committee-to-reconsider-about-600-tol-applications-previouslysubmitted-by/. Star Media Group Berhad, Malaysia. Accessed 20 Sept 2017

Charnsungnern M, Tantanasarit S (2017) Environmental sustainability of highland agricultural land use patterns for Mae Raem and Mae Sa watersheds, Chiang Mai province. Kasetsart J Soc Sci 38:169-174

Daim N (2017) NSC to lead monitoring of illegal land clearing at Cameron Highlands. New Straits Times Retrieved from https://www.nst.com.my/news/ nation/2017/05/240772/nsc-lead-monitoring-illegal-land-clearing-cameronhighlands. New Straits Times Press (Malaysia) Berhad. Accessed 20 Sept 2017

Department of Agriculture (DOA), Malaysia, (2017) http://www.doa.gov.my. Accessed 20 Nov 2017

District and Land Office (DLO) Cameron Highlands, (2017). Short briefing on TOLs Cameron Highlands. http://pdtchighlands.pahang.gov.my. Accessed 10 Sept 2017

District Council Cameron Highlands (DCCH) (2017). Short briefing RTDCH draft approach addressing environmental issues in Cameron Highlands. http:// www.mdcameron.gov.my. Accessed 10 Sept 2017

Diyabalanage S, Samarakoon KK, Adikari SB, Hewawasam T (2017) Impact of soil and water conservation measures on soil erosion rate and sediment yields in tropical watershed in the Central Highlands of Sri Lanka. Appl Geogr 79:103-114

Eisakhani M, Malakahmad A (2009) Water quality assessment of Bertam River and its tributaries in Cameron Highlands, Malaysia. World Appl Sci J 7(6):769-776

Eisakhani M, Pauzi A, Karim O, Malakahmad A (2011) Investigation and management of water pollution sources in Cameron Highlands, Malaysia. WIT Trans Ecol Environ 148:1-11. https://doi.org/10.2495/RAV110221.

Eisakhani M, Pauzi A, Karim O, Malakahmad A, Mohamed Kutty SR, Isa MH (2009) GIS-based non-point sources of pollution simulation in Cameron Highlands, Malaysia. Int J Environ Chem Ecol Geol Geophys Eng 3(3):1-5

Estoque RC, Murayama Y (2011) Spatio-temporal urban land use/cover change analysis in a hill station: the case of Baguio City, Philippines. Procedia Soc Behav Sci 21:326-335

Farina Y, Abdullah MP, Bibi N, Wan Mohd Khalik WMA (2016) Pesticides residues in agricultural soils and its health assessment for humans in Cameron Highlands, Malaysia. Malays J Anal Sci 20(6):1346-1358

Gasim M, Sahid I, Toriman E, Pereira JJ, Mokhtar M, Abdullah MP (2009) Integrated water resource management and pollution sources in Cameron Highlands, Pahang, Malaysia. Am Eurasian J Agric Environ Sci 5(6):725-732

Gasim MB, Surif S, Toriman ME, Abd Rahim S, Elfithri R, Pan IL (2010) Land use change and climate change of the Cameron Highlands, Pahang, Malaysia. 4th International Congress of The Islamic World Geographers (ICIWG2010). University of Sistan and Baluchestan, Zahedan

Hamdan ME, Man N, Md Yassin S (2014) Farmers sensitivity towards the changing climate in the Cameron Highlands. Agric J 9(2):120-126

Hamzah Z, Musa M, Saat A (2011) Study of selective metals accumulation in green mustard (Brasissca rapa var. parachinesis L.) from Cameron Highlands farmlands, Pahang. J Nucl Relat Technol 8(1):1-5 
Haron SH, Sahid I, Ab Rahman NF, Mohamad MSF, Mispan MR (2014) Non-point sources of pollution identification in Cameron Highlands using ArcGIS. Nationwide GIS Application Conference Proceedings, pp 1-11

Ismail MH, Che Ku Othman CKA, Abd Malek IA, Abdullah SA (2012) Land use trends analysis using SPOT-5 images and its effect on the landscape of Cameron Highlands, Malaysia. Asian J Geoinformatics 12(1):1-8

Ismail SNS, Zulkipli NF, Abidin EZ, Razali A, Awang S, Sulaiman FR (2017) Heavy metals contamination of river water and health risk in intensive agriculture area, Cameron Highlands (Malaysia). Unpublished research report

Jamil NR, Ruslan MS, Toriman ME, Idris M, Ab Razad A (2014) Impact of land use on seasonal water quality at highland lake: a case study of Ringlet Lake, Cameron Highlands, Pahang, From sources to solution. Chapter 74, pp 409 413. https://doi.org/10.1007/978-981-4560-70-2_74

Kannan HK (2018) More 'Op Gading' to curb land encroachment in Cameron Highlands. New Straits times. Retrieved from https://www.nst.com.my/news/ nation/2018/01/324143/more-op-gading-curb-land-encroachment-cameronhighlands. New Straits Times Press (Malaysia) Berhad. Accessed 13 Feb 2018

Khairiah J, Lim KH, Ahmad Mahir R, Ismail BS (2006) Heavy metals from agricultural soils from Cameron Highlands, Pahang and Cheras, Kuala Lumpur, Malaysia. Bull Environ Contam Toxicol 77:608-615. https://doi.org/10.1007/s00128-006-1106-8

Khairulmaini OS, Fauza AG (2010) Upper basin systems: issues and implication for sustainable development planning in Malaysia. J Geogr Reg Plann 3(11):327-338

Khalik WMAWM, Abdullah MP (2013) Status of metal concentrations in surface water of Bertam River, Malaysia. Centre for Water Research and Analysis (ALIR) UKM, Malaysia

Khalik WMAWM, Abdullah MP, Amerudin NA, Padli N (2013a). Physicochemical analysis on water quality status of Bertam River in Cameron Highlands, Malaysia. Journal of material and Environ Sci 4(4):488-495

Khalik WMAWM, Abdullah MP, Padli N, Amerudin NA (2013b) Assessment on nutrient status in water and sediment quality of Bertam River, Cameron Highlands. Int J Chem Sci 11(2):709-720

Kunasekaran P, Ramachandran S, Yacob MR, Shuib A (2011) Development of farmers' perception scale on agro-tourism in Cameron Highlands, Malaysia. World Appl Sci J (special issue of tourism and hospitality) 12:10-18

Lantican MA, Guerra LC, Bhuiyan SI (2003) Impacts of soil erosion in the Upper Manupali watershed on irrigated lowlands in the Philippines. Paddy Water Environ 1:19-26. https://doi.org/10.1007/s10333-002-0004-x

Lee GJ, Lee JT, Ryu JS, Hwang SW, Yang JE, Joo JH, Jung YS (2010) Status and soil management problems of highland agriculture of the main mountainous region in the South Korea. In: 19th world congress of soil science, soil solution for a changing world, Brisbane, Australia. Curran Associates, Inc. 57 Morehouse Lane Red Hook, NY 12571

Maharan NG (2015) RTB Lembah Bertam kukuh untuk hadapi kejadian banjir. Astro Awani Retrieved from http://www.astroawani.com/berita-malaysia/rtblembah-bertam-kukuh-untuk-hadapi-kejadian-banjir-81826. Astro Awani Network Sdn. Bhd, Malaysia. Accessed 13 Feb 2018

Mansor N, Mat Rashid K, Mohamad Z, Abdullah Z (2015) Agrotourism potential in Malaysia. International Academic Research. J Bus Tech 1(2):37-44

Mazlan N, Mumford J (2005) Insecticides use in cabbage pest management in the Cameron Highlands, Malaysia. Crop Prot 24:31-39. https://doi.org/10. 1016/j.cropro.2004.06.005

Mispan MR, Haron SH, Ismail BS, Abd Rahman NF, Khalid K, Abd Rasid MZ (2015) The use of pesticides in agriculture area, Cameron Highlands. Int J Sci Prog Res 15(1):19-22

Mohd Ariffin AR, Md Ali Z, Zainol R, Rahman S, Ang KH, Sabran N (2014) Sustainable highland development through stakeholders' perceptions on agro ecotourism in Cameron Highlands: a preliminary finding. SHS Web Conf 12:1-6. https://doi.org/10.1051/shsconf/20141201086

Oliver LHL, Che Mohd-Noor MH, Marzukhi MA, Mohd Musthafa SNA (2017) Social impact of agro-tourism on local urban residents. Case study: Cameron Highlands, Malaysia. J Malays Inst Plann 15(2):51-66

Radam A, Islam GMN, Ng KY, Arshad FM, Alias EF (2015) Impact of producing tomatoes under Malaysia-GAP certification on farming practices, Cameron Highlands. Food and Agriculture Organization of the United Nations (FAO), pp 1-24

Raj JK (2002). Land use changes, soil erosion and decreased base flow of rivers at Cameron highlands, Peninsular Malaysia. Geological Society of Malaysia Annual Geological Conference May 26-27, Kota Bharu, Kelantan, Malaysia.

Ramasamy R (2014) The flying TOLs of Cameron Highlands. Regional Environmental Awareness of Cameron Highlands Retrieved from http://reach. org.my. Regional Environmental Awareness Cameron Highlands, Malaysia. Accessed 20 Sept 2017

Rancangan Tempatan Daerah Cameron Highlands (RTD 2003-2015) (2018a). District Council Cameron Highlands (DCCH). Retrieved from http://www.kpkt. gov.my/resources/index/user_1/media_akhbar/press_release_3_disember_ Cameron_Highlands_2015. Accessed 12 Sept 2017

Rancangan Tempatan Daerah Cameron Highlands (RTD 2030) (2018b). District Council Cameron Highlands (DCCH). Retrieved from http://www.youblisher. com/p/1300753-Draf-Rancangan-Tempatan-Cameron-Highlands-2030-Jilid-1Part1/. Accessed 12 Sept 2017

Rasul MG, Islam MS, Yahaya FM, Alam L, Mokhtar M (2015) Effects of anthropogenic impacts on water quality in Bertam catchment, Cameron Highlands, Malaysia. Int J Ecol Environ Sci 41(1-2):75-86

Rendana M, Ab Rahim S, Idris WMR, Lihan T, Rahman ZA (2015) CA-Markov for predicting land use changes in tropical catchment area: a case study in Cameron Highlands, Malaysia. J Appl Sci 15(4):689-695

Riduan SD, Hamzah Z, Saat A (2009) In-situ measurement of selected water quality parameters in Ringlet's Lake, Cameron Highlands. Malays J Chem 11(1):122-128

Roozitalab MH, Serghini H, Keshavarz A, Eser V, de-Pauw E (2013) Sustainable agricultural development of highlands in central, West Asia and North Africa. International Center for Agricultural Research in the Dry Areas (ICADAR), pp 1-52

Rozimah R, Khairulmaini OS (2016) Highlands regions-land use change threat and integrated river basin management. Int J Appl Environ Sci 11(6):1509-1521

Saadati N, Abdullah MP, Zakaria Z, Rezayi M, Hosseinizare N (2012) Distribution and fate of $\mathrm{HCH}$ isomers and DDT metabolites in a tropical environment: case study Cameron Highlands, Malaysia. Chem Cent J 6:130-145

Sholagberu AT, UI Mustafa MR, Wan Yusof K, Ahmad MH (2016) Evaluation of rainfall-runoff erosivity factor for Cameron Highlands, Pahang, Malaysia. J Ecol Eng 17(3):1-8. https://doi.org/10.12911/22998993/63338

Sinar Harian (2012) Loji rawatan air Terla tercemar. Sinar Harian Retrieved from http://www.sinarharian.com.my/mobile/edisi/pahang/loji-rawatan-air-terlatercemar-1.28370. Accessed 20 Sept 2017

Singh R, Gautam N, Mishra A, Gupta R (2011) Heavy metals and living systems: an overview. Indian J Pharm 43(3):246-253

Sonter LJ, Johnson JA, Nicholson CC, Richardson LL, Watson KB, Ricketts TH (2017) Multi-site interactions: understanding the offsite impacts of land use change on the use and supply of ecosystem services. Ecosyst Serv 23:158-164

Tan KW, Beh WC (2016) Evaluation of water quality and benthic macroinvertebrates fauna relationship using principal component analysis (PCA): a case study of Cameron Highlands, Malaysia. Environ Manag Sustain Dev 5(1):1-22

Tan KW, Mokhtar M (2011) Emerging issues towards sustainable river basin management in Cameron Highlands, Malaysia. Environ Nat Resour J 9(2): 58-68

Tiraieyari N, Hamzah A, Abu Samah B (2014) Organic farming and sustainable agriculture in Malaysia: organic farmers' challenges towards adoption. Asian Soc Sci 10(4):1-7

Tolessa T, Senbeta F, Kidane M (2017) The impacts of land use/land cover change on ecosystem services in the central highlands of Ethiopia. Ecosyst Serv 23:47-54

Toriman ME, Karim OA, Mokhtar M, Gasim MB, Abdullah MP (2010) Use of info work RS in modelling the impact of urbanization on sediment yield in Cameron Highlands, Malaysia. Nat Sci 8(2):1-7

Utusan Malaysia (2012) Loji utama Cameron highlands ditutup akibat pencemaran. Utusan Malaysia Retrieved from http://ww1.utusan.com.my/ utusan/info.asp?y=2012\&dt=0228\&pub=Utusan_Malaysia\&sec=Terkini\&pg= bt_45.htm. Utusan Melayu (Malaysia) Berhad, Jalan Utusan, Off Jalan Chan Sow Lin, Kuala Lumpur. Accessed 20 Sept 2017

Weebers RCM, Idris H (2016) Decisions made on the development of the hill station of Cameron Highlands from 1884 till present day. J Surv Constr Prop $7(1): 1-12$

Yusoff SM, Yusof F, Arshad AF (2014) An analysis of local plan for development control at local planning level in the state of Selangor. Procedia Soc Behav Sci 153:574-584

Zin MHM, Ahmad B (2014) Mapping of government land encroachment in Cameron highlands using multiple remote sensing datasets. IOP Conference Series. Earth Environ Sci 1(18):1-7. https://doi.org/10.1088/1755-1315/18/1/ 012037. 